\title{
Hedge accounting and impact on financial market
}

\author{
Doan Van Dinh ${ }^{*, 1}$, Guangming Gong ${ }^{2}$ \\ ${ }^{1}$ Economics And Business, Hunan University, Hunan University and Faculty of Finance \& Banking, Ho Chi Minh City University of \\ Industry, Vietnam \\ ${ }^{2}$ Business School Hunan University, Changsha, Hunan, China
}

\section{Email address:}

citydinhninh@yahoo.com (D. Van Dinh)

\section{To cite this article}

Doan Van Dinh, Guangming Gong. Hedge Accounting and Impact on the Financial Market . Journal of Finance and Accounting .Vol. 1, No. 1, 2013, pp. 1-18. doi: 10.11648/j.jfa.20130101.11

\begin{abstract}
As published by the Vietnamese Chamber of Commerce and Industry (VCCI) and the World Bank (WB), in 2011 Vietnam had 622,977 entities in which 79,014 entities were bankrupted. This problem is concerned with financial risks or not and why?. Thus, the article reviews the use of derivative financial instruments for financial hedge and their effects to minimize the financial risks of the entities and bankrupt entities as well as their impacts on financial markets through decisions of investors and managers because their decisions are based on analysis results of financial statements. A country's accounting policy has not applied the derivative financial instruments for financial hedging, leading to affect that country's economy or not? Especially, the financial markets of Vietnam or countries with similar economies have not also applied the hedge accounting to their hedge activities. The article uses the accounting theories of international accounting standards and Generally Accepted Accounting Principles in the United States and applies the methods of data analysis in the financial statements to show the results of hedge accounting that are concerned with bankruptcy, financial risks and economy decline.
\end{abstract}

Keywords: Fair Value; Derivative Financial Instruments, Hedge Accounting, Vietnamese Financial Market

\section{Introduction}

\subsection{Background}

Hedging activities are necessary for the entities and investors. Even though the entities and investors don't expect the risks, the risks are still always present in all investment decisions or transactions of the entities, investors, and these risks can transform their dreams from "sweet dreams " to " bitter consequence". Depending on the risk level can cause financial losses, or it makes the entities in the exhausted financial state and even bankrupt. Therefore, the entities or investors need to consider hedging activities in order to minimize the damage caused by the risks for the entities and investors. Many financial institutions and entities have used the derivative financial instruments to hedge exposure to different risks (e.g. Interest rate risk, foreign exchange risk, commodity risk, etc....).

The great usefulness from hedge accounting is use of the derivative instruments. So, the Financial Accounting Standards Board (FASB) formally considered the derivative instruments accounting for hedging activities at the conference in 1986 and issued indispensable financial account- ing and reporting standards in relation to financial instruments. From 1990 to 1998 , the FASB issued and amended the accounting standards as follows:

Statement No. 105 "Disclosure of Information about Financial Instruments with Off - Balance - Sheet Risk and Financial Instruments with Concentrations of Credit Risk" (Issued in March 1990).

Statement No. 107 "Disclosure about Fair Value of Financial Instruments" (issued in December 1991) for replacement of Statement No. 105.

Statement No. 115 “Accounting for Certain Investments in Debt and Equity Securities" (issued in 1993).

Statement No. 119 "Disclosure about Derivative Financial Instruments and Fair Value of Financial Instruments" (issued in October 1994) for replacement of Statement No. 133.

After many discussions of the FASB, the FASB decided to issue Statement No. 133 "Accounting for Derivative Instruments and Hedging Activities" in July 1998. In the process of applying Statement No. 133, the entities realized the complicated derivative instruments accounting and were not satisfied with application to their hedge activities. Therefore, the FASB issued Statement of Financial Ac- 
counting Standards (FAS) No. 149 and amended Statement No.133 on Derivative Instruments and Hedging Activities (issued in April 2003). The FAS No. 149 applied accounting and reporting for derivative financial instruments more clearly including: Certain derivative instruments embedded in other contracts (collectively referred to as derivatives) and hedging activities under FAS Statement No. 133 "Accounting for Derivative Instruments and Hedging Activities". The FASB issued FAS No. 138 "Accounting for Certain Derivative Instruments and Certain Hedging Activities in June 2000. The essential contents of standards were concerned with the derivative instruments accounting of foreign currency. In 2009, with a complete effort of the FASB, they issued Accounting Standards Codification (ASC), after that all former derivative instruments accounting standards and hedging activities were recognized on ASC 815 "derivatives and hedging". The hedge accounting has been applied to the U.S. economy for a long time, and it has minimized their financial risks, at the same time, it has played an important role in promoting the economic development and the entities has applied hedge accounting to successfully prevent the financial risks.

Besides, the International Accounting Standards Board (IASB) has also studied and promulgated the international accounting standards in relation to hedge accounting such as: International Accounting Standard (IAS) IAS 32 "Financial Instruments: Disclosure and Presentation" in 1995, After a further period of effort, IAS 39 "Financial Instruments: Recognition and Measurement" was issued in 1999 to deal with the matters not covered in IAS 32. In 2008, IAS 39 was amended for ${ }^{1}$ Annual Improvements to the International Financial Reporting Standards (IFRSs, 2007). In 2009, IAS 39 was amended for Annual Improvements to IFRSs 2009, Classification and measurement Provisions of IAS 39 was replaced by IFRS 9 "financial instruments" that has been effective on 1 January 2013 (a new financial instruments standard) and with earlier application permitted by the IASB to aim at helping countries be able to apply financial instruments accounting standards to their economy. However, the application of international accounting standards to the economy of each country faces many difficulties. Because each country has a particular economy and the accounting policy is closely connected to its political system. In addition, the language difference leads to their limited understanding about the contents and methods of the international accounting standards. This problem is the biggest obstacle for the entities to apply the global common uniform accounting system.

Currently, although Vietnam hasn't issued the financial instruments accounting standards yet, in November 6, 2009 the Vietnamese Ministry of Finance issued Circular No. $210 / 2009 / \mathrm{CMOF}$ to guide the application of international

\footnotetext{
1 (Each year the Board considers minor amendments to IFRSs in an annual improvements project. The amendments are proposed in an omnibus Exposure Draft)
}

accounting standards (financial statement presentation and financial instruments disclosure) and this Circular are applicable to all entities' financial business fields. These international accounting standards include IAS 32 Financial Instruments: Presentation; IAS 39 Financial Instruments: Recognition and Measurement; International Financial Reporting Standards (IFRS 7) Financial Instruments. However, the drafted guideline contents are also unclear and irrelevance, leading to the entities' the practical application of this circular face many difficulties.

\subsection{Literature Review}

In the research process, the previous researches on hedge accounting and fair value hedge are reviewed such as the "Basic Principles of Hedge Accounting" of Cristina Aurora BuneaBontas (2009), MPRA Paper No. 17072, posted 3), the author wrote about the development of the capital market and the use of new techniques to manage the risks, also evaluated the effectiveness of prevention. The author could identify the risks related to cash flow and the effect of the asset fair value and liabilities or the value of the cash flows related to future transactions of the entities. Moreover, the author's article emphasized that the financial risks in international business such as price risk; credit risk; liquidity risk could be hedged by using financial instruments, especially derivatives. The author used the analysis methods and the basic principles of hedge accounting under IAS 39 "recognition and measurement". Also the same idea with this author, a group of authors including Bridget Gandy, Roger Merritt, Mark Oline, Joseph St. Denis and William Mann wrote "Hedge Accounting And Derivatives Study For Corporate Disclosure, Hedge Accounting, And Restatement Risk" (Journal of Derivatives Accounting, Vol. 2, No. 2 (2005) 231245). In this article, they studied derivatives accounting and disclosure between the entities except financial institutions. They also found out that the derivative was a part of the risk management framework for major entities' debt issuers and allowed active management of interest rate, foreign exchange, commodity price, equity and financial liability. Furthermore, they presented the main results on key industry issues and the analysis of the effects from the use of hedge methods and its results such as Accounting for Derivatives, Aggregate Financial Statement Effects and Hedge Accounting Impact on ratios. For "Divergent FAS133 and IAS39 Interest Rate Risk Hedge Effectiveness: Problem and Remedies" written by James. Bodurtha, JR (Journal of Derivatives Accounting, Vol. 2, No. 1 (2005) 1-13) that mentioned the effect of prophylactic interest rate swap, property and debts. They based on accounting principles of SFAS 133, IAS39 and shortcut method (SCM) to evaluate the effectiveness of hedge specification of interest rate risk. They gave the solutions to the major problems in relation to the capital requirements of banks (and insurance). The "HeatTM (Hedge Effectiveness Analysis Toolkit): A Consistent Framework For Assessing Hedge Effectiveness Under IAS 39 and FAS 133 From Jpmorgan". The "Effect of deriva- 
tive accounting rules on corporate risk management behavior" written by Haiwen Zhang (journal of Accounting and Economics 47 (2009) 244-264) showed that the effect of derivative instruments accounting standards (SFAS No133) was applied to the entity's risk management. This author analyzed the behavior of managers when they applied derivative instruments to prevent the financial risks and found out the volatility of cash flows and risk exposures in connection with interest rate, foreign exchange rate and significant decrease of commodity price. The author used multiple regression model to analyze impact factors that were interest rate, foreign exchange rate and commodity price.

The same purpose with the above authors' research, the following authors also had similar researches such as: "The crisis of fair value accounting: Making sense of the recent debate" written by Christian Laux and Christian Leuz (Accounting, Organizations and Society 34 (2009) 826-834); "Fair Value Accounting And The Management of The Firm" of Benzion Barlev And Joshuarene Haddad (Critical Perspectives on Accounting (2003) 14, 383-415); "Derivative financial instruments used in Australia" of a group of authors including Henk Berkman, Michael E. Bradbury, Phil Hancock and Clare Innes, or "Using and Accounting for Derivatives: An International Concern" of Coauthor Lil E. Crawford, Arlette C. Wilson and Barry J. Bryan (Journal of International Accounting, Auditing \& Taxation, 6 (1): 111121).

Through the assessment of the above author's researches showing that all authors based on hedge accounting theories under the FASB or the IASB to apply to hedge activities and used analytical methods to analyze factors impacting on the entity's financial risks. In addition, the authors had a common opinion on the use of derivative financial instruments for hedging activities. Otherwise, the authors tended to use a purely theoretical method or analysis method of the impact factors on the financial market and risk management (interest rate, foreign exchange rate and commodity price, etc.) of the multiple regression model or other mathematics methods to solve related financial issues. The authors did not use an analysis method of financial indicators while almost managers or investors well understood this method. In fact, the authors' methods were complex and difficult for the investors or managers to understand and apply it.

From limitations above, the article applies derivative instruments accounting under the FASB to apply to specific economic events. At the same time, it adjusts the interest rate, foreign exchange rate, and commodity price according to prices of derivative instruments (Forward Contracts, Swap Contracts, Future Contracts and Option Contracts) to make financial statements. Also base on specific economic events, the article applies derivative instruments accounting and make financial statements. After that, it uses financial analysis method to analyze different results of two methods and finds out the factors that can affect strategic decisions of the investors or managers.

\section{The Hedge Accounting and Derivative Instruments}

\subsection{Hedge Accounting}

The derivative financial hedge accounting is essential for development of the financial markets and risk minimizing for the entity's transactions. This hedge accounting is applied to the financial assets and financial liabilities and brings a high hedge effect to the economy. A derivative is a hedge instrument applying to hedge forecast transactions that occur. The derivative instruments include future contracts, swap contracts, option contracts and forward contracts. In addition, the hedge accounting is the use of appropriate accounting methods under the international accounting standards (IAS) or Statement of Financial Accounting Standards (SFAS) 133, the entities can apply these methods to prevent the financial risks from transactions which occur. The derivative instruments are basic price, or are rated to the measurement unit, a defined amount and payment terms. Accounting's quality depends on all derivative instruments measurements at fair value. The firms' aims is the use of hedge accounting to minimize the risk of investment and business. The hedge accounting under the ASC 815 are classified into three categories as follows:

Hedged fair value: hedged items are existing assets or liabilities and unrecognized firm commitments related to the purchase and sale in order to minimize risks for changes in fair value of a recognized asset or liability. These items are hedged and the derivative instruments are evaluated at the fair value on the last day of the quarter or financial statements year. Loss or profit from these items is immediately recognized in income.

1). Hedged cash flow: The exposure hedge instruments deal with variable expected value of cash flows in future connected to the risks. This loss may be related to recognition of the assets or liabilities (as an exchange rate hedge) or foreseen transactions (purchase and sale) to minimize the risks of unpredictable variability of the cash flow in future. The derivative instruments are evaluated at the market price at the end of the year and are recognized as an asset or a liability. This gain or loss can be recognized in other comprehensive income in connection with deferring until the transaction affects income. The accumulated profit or accumulated loss of other comprehensive income is recognized in equity on the balance sheet.

2). Hedge of a net investment of subsidiaries in a foreign operation:

For the hedge accounting based on the underlying principle of IAS 39, the entities apply the hedge accounting when a hedged forecast transaction occurs and results in the recognition of a financial asset or a financial liability. The gain or loss is recognized in other comprehensive income and the entities are not adjusted initial carrying amount of the asset or liability. However, the remains in equity and the gain or loss is reclassified from the equity. 
This gain or loss can be recognized in profit or loss, but it is consistent with the recognition of gain and loss on the asset or liability as a reclassification adjustment. For result in the recognition of a nonfinancial asset or a nonfinancial liability, the entities can apply a basis adjustment or retain the hedging gain or loss in equity. The entities can also reclassify it from the equity and recognize in profit or loss when the asset or liability affects profit or loss as a reclassification adjustment. This hedge accounting definition under IAS 39 is also classified into three categories as follows:

3). Fair value hedge: a hedge of the exposure to changes in fair value of a recognized asset or liability or an unrecognized firm commitment, or an identified portion of such an asset, liability or firm commitment that are attributable to a particular risk and could affect profit or loss.

4). Cash flow hedge: a hedge of the exposure to variability in cash flows that is attributable to a particular risk associated with a recognized asset or liability (such as all of or some future interest payments on variable rate debt) or a highly probable forecast transaction and could affect profit or loss.

5). Hedge of a net investment in a foreign operation: Foreign operation is an entity that is a subsidiary, association, joint venture or branch of a reporting entity, the activities of which are based on or conducted in a country or currency other than those of the reporting entity (defined in IAS 21).

Generally, almost these hedged items based on the underlying principles of the IASB and FASB are equivalent converging. The IASB and FASB have the same opinion about the application of derivative instruments for hedging activities.

\subsection{Derivative Instruments}

Currently, almost entities apply the derivative instruments to hedge accounting including forward contracts, swap contracts, option contracts and future contracts.

\subsubsection{For Forward Contracts}

The forward contracts apply to big amounts of goods transactions (common goods, financial assets, exchange rates, etc.) and are determined at a time in the future at a fixed price that is agreed under regulation at the time of contract signing. From date of contract signing to the date of contract maturity is called as contract period and the contract's payment date is called as the date of maturity.

For the entities that trade foreign currency or imported goods and pay foreign currency, formula of forward rate is as follows:

- F - The forward rate

- $r_{d}$ - The interest rate of the valued currency, i.e. Vietnam Dong (VND) rates

- $r_{y}$ - The interest rate of the basic currency, i.e. United States Dollar (USD) rates

- $\mathrm{S}$ - The current rates, $\mathrm{S}=\mathrm{USD} / \mathrm{VND}$

$$
F=s \times \frac{\left(1+r_{d}\right)}{\left(1+r_{y}\right)} \quad \text { Formula }(1)
$$

The formula (1) is assessed as follows:

First case: if the interest rate of evaluating currency is greater than the interest rate of the quoted currency:

$$
r_{d} \succ r_{y} \Rightarrow 1+r_{d} \succ 1+r_{y} \Rightarrow \frac{\left(1+r_{d}\right)}{\left(1+r_{y}\right)} \succ 1 \Rightarrow F \succ s .
$$

It is called as an increase in the forward rate point.

Second case: if the interest rate of evaluating currency is less than the interest rate of the quoted currency:

$$
r_{d} \prec r_{y} \Rightarrow 1+r_{d} \prec 1+r_{y} \Rightarrow \frac{\left(1+r_{d}\right)}{\left(1+r_{y}\right)} \prec 1 \Rightarrow F \prec s .
$$

It is called as deduction of forward rates point.

Combining two cases above we see that the forward rate can be summarized as follows: $\mathrm{F}$ equal to $\mathrm{S}$ plus forward point, in which the forward point can be positive or negative and is determined based on the current price ratio and interest rate differences between evaluated currencies and quoted prices. Assuming that the fiscal year is 360 days and the interest rate is percentage per year.

+ Forward rate of purchase:

$$
F_{P}=s_{P}+\frac{s_{p} \times(L g t(V N D)-L c v(N T)) \times \mathrm{N}}{100 \times 360}
$$

+ Forward rate of sale:

$$
F_{s}=s_{s}+\frac{s_{s} \times(\operatorname{Lcv}(V N D)-\operatorname{Lgt}(N T)) \times \mathrm{N}}{100 \times 360}
$$

Formula (3)

In which:

$F_{P}$ is forward rate of purchase and $s_{P}$ is the current rate of purchase,

$F_{s}$ is forward rate of sale and $S_{s}$ is the current rate of sale.

$\operatorname{Lgt}(V N D)$ is interest rate of deposits and $\operatorname{Lcv}(V N D)$ is lending interest rate in Vietnam Dong (VND).

$\operatorname{Lgt}(N T)$ is interest rate of deposits and $\operatorname{Lcv}(N T)$ is lending interest rate in foreign currency.

$\mathrm{N}$ is the number of days of the forward contracts.

\subsubsection{Swap Contracts}

Swaps are foreign exchange transactions that simultaneously include both transactions: purchase and sale of the same amount of currency among different countries, in which the maturity of two different transactions and rates of two transactions are determined at the time of the contract signing.

Characteristics of foreign exchange (FOREX) Swaps.

+ In the swap contracts, if the first partner carries out the first purchase and last sale, the second partner will carry out the first sale and last purchase (or vice versa). 
+ Purchase and sale are signed on the same day of the contract signing date (trading days) in the same contract and with the same partner (or vice versa).

+ The amount of purchase and sale of currency is equal for both sides (purchase and sale) of swap contracts.

Purchase value and sale value is on the same date.

\subsubsection{Option Contracts}

Call option contracts: an agreement allows a buyer having a call option to buy a seller's property at a fixed price on maturity of the contract.

Put option contracts: an agreement allows a seller having put option to sell his property to a buyer at fixed price on the maturity of the contract. This contract characteristic is not binding on call and put option, but a buyer of a call option or a seller of a put option has to pay transaction fees before or on the contract maturity.

\subsubsection{The Future Contracts}

Future contract is a standardized contract and goods transactions on the central exchange (broker) that the partners can participate to buy or sell a certain commodity (normal commodity or financial assets) at a fixed price and at a fixed date in the future. This date is called as the delivery date (the last day). Price is determined at the date of contract signing and is called as the future price while the price of the goods on delivery is called as settlement price. Generally, the more gradually to the delivery date, the settlement price will converge towards the future price. The future contracts have difference with forward contracts as follows:

Future contracts: purchase and sale are agreed by brokers, partners are randomly determined at the central exchange. These contracts are a direct agreement between the two parties to the contract, and the parties define their partners.

Future contracts are traded on the central exchange. The forward contracts are contrary.

Future contracts are calculated daily at market prices (marking to market). The forward contracts are paid at maturity.

Future contracts on the goods central exchange and the stock central exchange are defined as follows:

Future prices are determined on the basis of establishing the relationship between the future price and the spot price. Assuming that a firm will join in the future contracts in goods central exchange.

Loan is $S_{0}$ with interest $\left(r_{f}\right)$; using this money to buy basis asset;

$F_{0}$ is the future price (i.e. at maturity, we must sell the basis asset at $F_{0}$, but at this time there is no exchange of currency or asset). During the time from now to the maturity of future contract, the basis asset makes a profit which is called as D (e.g. the basis asset is stock, stock dividend D is paid). Value of basis assets based on the market price is $S_{T}$.
Table 1 Marking to market

\begin{tabular}{|c|c|c|c|}
\hline Date & $\begin{array}{l}\text { Daily variable } \\
\text { price }\end{array}$ & $\begin{array}{l}\text { First period } \\
\text { of cash flow }\end{array}$ & $\begin{array}{l}\text { Last period of } \\
\text { cash flow (formula) }\end{array}$ \\
\hline & Loan $\left(S_{0}\right)$ & $S_{0}$ & $\begin{array}{c}-S_{0} \text { Multiply } \\
\left(1 \text { plus } r_{f}\right)\end{array}$ \\
\hline & Market price is $S_{0}$ & $-S_{0}$ & $S_{T}$ plus D \\
\hline & $\begin{array}{l}\text { Settlement } \\
\text { date of the contract }\end{array}$ & 0 & $F_{0}$ minus $S_{T}$ \\
\hline
\end{tabular}

The last period of cash flow equals to $\left[F_{0}-S_{0} \times\left(1+r_{f}+D\right)\right]$. In principle, the firms cannot get profit from the different price, leading to the conclusion that at the beginning the firm gets the value of assets equal to $0 \mathrm{VND}$, the end of the period the firm gets the value of assets equal to 0VND. That means: $\left[F_{0}-S_{0} \times\left(1+r_{f}+D\right) \mid=0\right.$ or $F_{0}=S_{0} \times\left(1+r_{f}\right)-D=0$ $F_{0}$. Called d equal to $\mathrm{D}$ per $S_{0}$ (dividend rate), so $F_{0}=S_{0} \times\left(1+r_{f}-d\right)$, the above formula for calculating future price is called as cost relationship of financial assets archives that the maturity of future contract is $\mathrm{T}$ then: $F_{0}=S_{0}\left(1+r_{f}-d\right)^{T}$, the future price at same time is $\mathrm{t}$, and the formula is as follows:

$$
F_{t}=S_{t}\left(1+r_{f}-d\right)^{\mathrm{T}-\mathrm{t}} \text { Formula }
$$

When the futures contracts are settled, leading to $\mathrm{t}$ equal to $\mathrm{T}$ and $F_{T}=S_{T}$.

From accounting theories and financial methods above, they are applied to data analysis of the article below.

\section{Data Analysis and Sense of Derivative Financial Instruments in Hedge Activities}

This article is based on Rationale theories above to analyze economic events that occurred in Vietnam economy. Because, the economy of Vietnam may represent countries that have similar economies or have transitioned economy. The "Similarities and Differences Comparison of IFRS and Thai GAAP, Vietnamese GAAP, Cambodian GAAP and Lao GAAP" of PricewaterhouseCoopers shows that: Thai GAAP does not include a specific standard covering the hedge accounting. Also, it has no specific accounting standards dealing with the recognition and measurement of derivatives" or Cambodian Accounting Standards (CAS) has applied the contents of CAS being equivalent to contents of IAS. However, they do not have financial instruments accounting standard that is equivalent to IAS 39, etc. Thus, with actual data (market price, interest rate and exchange rate that varies from day to day on the market), it is analyzed to show the effects of hedge activities as follows: 


\subsection{Supposed Economic Events ${ }^{2}$}

According to new statistics published by the General Administration of Customs, from January to the end of the first quarter of 2013, gross domestic turnover rate of exports and imports reached 59.25 billion U.S. dollars, up $18.7 \%$ compared with the same period in 2012 . The major exported commodities remained increase, in which many commodities have an export turnover of more than $\$ 1$ billion such as :

Crude oil: Crude oil exports in the first 3 months of 2013 reached more than 2 million tons, an increase of $16.3 \%$ and an output value reached 1.85 billion U.S. dollars, up $7.6 \%$ compared to the same period in 2012. Exports of crude oil increased by $\$ 130$ million due to increased turnover of 280 million USD and drop prices $(7.5 \%)$ lead to the value of exported commodities fell by $\$ 150$ million.

Coffee: As of January 3-2013 coffee export was beyond the rice export (higher turnover of 326 million dollars) and agricultural products become a major export of the country (30\% density). The statistics show that the first quarter of 2013 the exported coffee volume reached 476 thousand tons and valued at $\$ 1.02$ billion, down $10.9 \%$ in volume and $7.7 \%$ in value over the same period of last year etc. (Source : General Department of Customs).

Although Vietnam exports the crude oil, Vietnam also imports 100 percentages of petroleum products. The world crude oil prices rise, making internal gasoline prices also increased. On the other hand, the revenues from crude oil exports also increased. However, the ability to export crude oil of Vietnam remains limited while demand increases constantly. In fact, the revenues from crude oil export are not enough for the import cost of petroleum products.

By reasons above, the article is assumed by economic events occurring as follows:

\subsubsection{First Economic Transactions}

* In January 2013, the firm had the following transactions:

Imported 100 buckets of crude oil, the market price was 91. 82 USD/ bucket, the exchange rate was 20,820 (VND/USD), they were unpaid.

Sold 50 buckets, the market price was 2,294,031 $\mathrm{VND} /$ bucket, and paid in cash.

Note: The price of crude oil and exchange rate from Source: Journal of ministry of finance and website: vietcombank.com.vn of the Bank.

\subsubsection{Second Economic Transactions}

*In February 2013, the firm had transactions of foreign currency with the Bank (Techcombank) as follows:

Sold foreign currency with an amount of 200,000 USD (beginning debit balance), current exchange rate was 20,855 (VND/USD), historical exchange rate was 20,720 (VND/USD), exchange rate on the payment date of firm

\footnotetext{
${ }^{2}$ This supposition basis in the Vietnamese market
}

was 20,815 (VND/USD).

In March 2013, purchased foreign currency to pay the first economic transactions with an amount of 120,000 USD, current exchange rate was 20,855 (VND/USD), spot rate was 20,960 VND/USD. (Deposit interest rate of USD is $2 \%$ / year, deposit interest rate of VND is $9 \%$ / year, lending interest rate of USD is $5 \%$ / year, lending interest rate of VND is $15 \%$ / year, those data from the Source: website: vietcombank.com.vn of the bank).

\subsubsection{Third Economic Transactions}

In March 2013, the firm bought 5,000 shares (Investment Corporation and Prices Evaluation of Oil and Gas $\mathrm{PIV}$ ), par value share was $10,000 \mathrm{VND} /$ share, and the market price was 22,000 VND / share, paid in cash.

Note: The variable security's price on stock market from $15,000 \mathrm{VND} / \mathrm{sh}$ are to $25,000 \mathrm{VND} /$ share. (Stock prices by source Website: cophieu68.com).

\subsubsection{Final Economic Transactions}

In March 2013, the firm bought 20 tons of Robusta coffee, the paid price was $44,500,000 \mathrm{VND} /$ ton and paid in cash.

Note: The volatility of market price was as follows: in January 2013, coffee price was 40,700,000 VND/ton; in February 2013, coffee price was 39,500,000 VND/ton and coffee price in March 2013 was 44,500,000 VND/ton. (Coffee prices by Source: Y5CAFE: Website: GIACAPHE.COM).

\subsection{Application of Derivative Instruments for Hedging Activities}

\subsubsection{First Economic Transactions}

The firm A uses forward contracts and the maturity of the contract is 3 months; the current price of crude oil is 90.817 USD / bucket. The forward price is 90.82 USD/bucket (using formula 2).

$$
F_{P}=90.817+\frac{90.817 \times(0.9-0.5)) \times 3}{100 \times 360}=90.82 \mathrm{USD} / \text { bucket }
$$

The following is double entry:

\subsubsection{Second Economic Transactions}

The firm also uses swap contracts for purchase and sale of foreign currency with the Bank (Techcombank) and the maturity of the contract is 3 months. The bank and the firm identify and agree upon forward rate and they swap this exchange rate together with relationship of purchase and sale as follows: (using formula 2 and 3 ).

The forward rate for sale bases in $S_{s}=20,855$ $(\mathrm{VND} / \mathrm{USD}), \operatorname{Lcv}(V N D)=15 \% /$ year, $\operatorname{Lgt}(N T)=2 \% /$ year, $\mathrm{N}=3$ months.

$$
F_{s}=20,855+\frac{20,855 \times(1.5-0.2)) \times 3}{100 \times 360}=20,857
$$

The forward rate for sale equals to 20,857 (VND/USD).

The forward rate for purchase bases on $S_{P}=20,855$ $(\mathrm{VND} / \mathrm{USD}), \operatorname{Lgt}(V N D)=9 \% /$ year, $L c v(N T)=5 \% /$ year 
and $\mathrm{N}=3$ months.

(VND/USD). The following is double entry:

$$
F_{P}=20,855+\frac{20,855 \times(0.9-0.5)) \times 3}{100 \times 360}=20,856 \mathrm{VND} / \mathrm{USD}
$$

The forward rate for purchase equals to 20,856

Table 2. - purchase and sale of oil at forward price (Forward contract: 90.82 USD / bucket \& exchange rate: 20,820 (VND/USD)

\begin{tabular}{llll}
\hline Date and Explanation & Accounts & Debits & Credits \\
\hline January 2013 & Inventories (crude oil) & $191,169,240$ VND & \\
1 Purchase of crude oil & Account payable & & $189,087,240$ VND \\
Difference of two prices & Other comprehensive income (OCI) & & $2,082,000$ VND \\
& Cash & $114,701,544$ VND & \\
Sale of crude oil & Revenue - sale of goods & & $114,701,544$ VND \\
3 Cost of sale & Cost of goods sold & $95,584,620$ VND & \\
Total: & Inventories (crude oil) & & $95,584,620$ VND \\
\hline
\end{tabular}

Note:

Forward price is $\$ 90.82 /$ bucket $x 100$ buckets $=\$ 9,082 \Leftrightarrow: \$ 9,082 \times 20,820(\mathrm{VND} / \mathrm{USD})=189,087,240 \mathrm{VND}$.

The market price is $\$ 91.82 /$ bucket $x 100$ buckets $=\$ 9,182 \Leftrightarrow: \$ 9,182 \times 20,820(\mathrm{VND} / \mathrm{USD})=191,169,240 \mathrm{VND}$

Difference of the two prices is (\$91.82/bucket minus $\$ 90.82 /$ bucket) $x 100$ buckets $=\$ 100 \Leftrightarrow: \$ 100 \times 20,820(\mathrm{VND} / \mathrm{USD})=2,082,000 \mathrm{VND}$.

Sales revenue of goods: 50 buckets $x$ 2,294,031VND/bucket $=114,701,544$ VND.

Cost of sale: price unit $=191,169,240 \mathrm{VND} / 100$ buckets $=1,911,692 \mathrm{VND} /$ bucket, and then: 50 buckets $x$ 1,911,692 VND/bucket $=95,584,620 \mathrm{VND}$.

Table 3. - forward rate: $F_{P}=20,856 ; F_{S}=20,857(V N D / U S D)$

\begin{tabular}{lll}
\hline Date and Explanation & Accounts & Debits \\
\hline $2 / 2013$ & Cash & $4,171,400,000 \mathrm{VND}$ \\
1 Sale of foreign currencies & Inventories (foreign currencies) & $4,144,000,000 \mathrm{VND}$ \\
Difference of Exchange Rate & Revenue - Financial Activities & $27,400,000 \mathrm{VND}$ \\
& Inventories (foreign currencies) & $2,515,200,000 \mathrm{VND}$ \\
2 Purchase of foreign currencies & Cash & $2,502,720,000 \mathrm{VND}$ \\
Difference of two exchange rates & Other comprehensive income & $12,480,000 \mathrm{VND}$ \\
Total: & & $\mathbf{6 , 6 8 6 , 6 0 0 , 0 0 0 ~ V N D}$ \\
\hline
\end{tabular}

Note:

Sale of foreign currencies: the forward rate: 4,171,400,000 VND =200,000 USD $x 20,857$ (VND/USD).

Historical exchange rate: 4,144,000,000 VND = 200,000 USD $x 20,720(\mathrm{VND} / \mathrm{USD})$.

Difference of two exchange rates between forward rate and historical rate: 27,400,000 VND equal to 200,000 USD multiply [20,857 (VND/USD) minus $20,720(V N D / U S D)]$.

Purchase of foreign currencies, the spot rate: 2,515,200,000 VND =120,000 USD $x 20,960$ (VND/USD).

The forward rate: 2,502,720,000 VND =120,000 USD $\times 20,856(V N D / U S D)$.

Difference of two exchange rates between forward rate and spot rate: 12,480,000 VND equal to 120,000 USD multiply [20,960 (VND/USD) minus 20,856 $(V N D / U S D)]$.

\subsubsection{Third Economic Transactions}

The firm uses option contracts to buy securities, the transaction fee is $1,000 \mathrm{VND} /$ share. The supposed price of 
the call option is $18,000 \mathrm{VND} /$ share. (Note: No use option lows: contracts for "short selling"). The double entry is as fol-

Table 4. - the price of call option: 18,000 VND/share

\begin{tabular}{llrl}
\hline Date and Explanation & Account & Debits & Credits \\
\hline $3 / 2013$ & Inventories (Common Stocks) & $115,000,000$ VND & $90,000,000$ VND \\
Purchase of securities & Cash & $5,000,000$ VND \\
Transaction fee of call option & Cash & $20,000,000$ VND \\
Difference of two prices & Other Comprehensive income & & $\mathbf{1 1 5 , 0 0 0 , 0 0 0 ~ V N D}$ \\
Total: & & $\mathbf{1 1 5 , 0 0 0 , 0 0 0 ~ V N D}$ & \\
\hline
\end{tabular}

Note:

Following the price of call option: 90,000,000 VND = 5,000 shares $x 18,000 \mathrm{VND} /$ share.

Following the market price: $110,000,000 \mathrm{VND}=5,000$ shares $x 22,000 \mathrm{VND} /$ share.

Fee of security transactions: 5,000,000 VND = 5,000 shares $x$ 1,000 VND/share.

Total value of common stocks: $115,000,000 \mathrm{VND}=110,000,000 \mathrm{VND} 5,000,000 \mathrm{VND}$

The difference of two prices between price of call option and market price: 20,000,000 VND equal to 5,000 shares multiply (22,000 VND/share minus $18,000 \mathrm{VND} /$ share).

\subsubsection{Final Economic Transactions}

The firm also uses future contracts to buy Robusta coffee, the future price is $40,700,000 \mathrm{VND} /$ ton, the maturity of the contract is 3 months, the interest rate is $9 \% /$ year, the current price is $32,761,895 \mathrm{VND} /$ ton (using formula 4).

$$
\begin{gathered}
F_{0}=S_{0}\left(1+r_{f}\right)^{\mathrm{T}} ; \\
F_{0}=32,761,895 \times(1+0.07)^{3}=40,700,00 \mathrm{VND} / \text { ton }
\end{gathered}
$$

Before taking part in the central exchange and they have an initial margin on clearing, it is $814,000,000$ VND until settlement date of contract.

\begin{tabular}{|c|c|c|c|c|}
\hline Date & No & $\begin{array}{l}\text { Marking to Market } \\
\text { A }\end{array}$ & $\begin{array}{l}\text { Gain } / \text { loss } \\
\text { B } \\
\text { B2=A2A1; B3=A3 }-\mathbf{A 2}\end{array}$ & $\begin{array}{l}\text { Last period of cash flow } \\
\mathrm{C} \\
\mathrm{C} 2=\mathrm{C} 1 \mathrm{~B} 2 \text { and } \mathrm{C} 3=\mathrm{C} 2 \mathrm{~B} 3\end{array}$ \\
\hline $1 / 2013$ & 1 & $40,700,000 \mathrm{VND} /$ ton & $0 \mathrm{VND}$ & $814,000,000 \mathrm{VND}$ \\
\hline $2 / 2013$ & 2 & $39,500,000 \mathrm{VND} /$ ton & $(1,200,000) \mathrm{VND} \times 20$ tons & $790,000,000 \mathrm{VND}$ \\
\hline $3 / 2013$ & 3 & $44,500,000 \mathrm{VND} /$ ton & $5,000,000 \mathrm{VND} \times 20$ tons & $890,000,000 \mathrm{VND}$ \\
\hline
\end{tabular}

Table 5. - Daily Notes on a variable price of the basis asset

The following is double entry: 
Table 6. - the future price: $40,700,000 \mathrm{VND} / \mathrm{ton}$

\begin{tabular}{llll}
\hline Date and Explanation & Accounts & Debits & Credits \\
\hline $3 / 2013$ & Inventories (Robusta coffee) & $890,000,000 \mathrm{VND}$ & \\
Purchase of Robusta coffee & Cash & & $714,000,000 \mathrm{VND}$ \\
Difference of two prices & Other comprehensive income. & & $76,000,000 \mathrm{VND}$ \\
Total: & & $890,000,000 \mathrm{VND}$ & $890,000,000 \mathrm{VND}$ \\
\hline
\end{tabular}

Note:

Following the market price: $890,000,000 \mathrm{VND}=20$ tons $x 44,500,000 \mathrm{VND} /$ ton.

Following future price: $814,000,000 \mathrm{VND}=20$ tons $x 40,700,000 \mathrm{VND} / \mathrm{ton}$.

The difference of two the prices: 76,000,000 VND equal to 20 tons multiply (44,500,000 VND/ton minus 40,700,000 VND/ton)

3.3. Non-Application of Derivative Instruments for Hedging Activities

\subsubsection{First Economic Transactions}

In case, the firm does not apply derivative instruments to hedge activities, the occurring economic events have no difference in price and interest rate. Therefore, the firm does not adjust it and the double entry is as follows:

Table 7. - the market price

\begin{tabular}{|c|c|c|c|}
\hline Date and Explanation & Accounts & Debits & Credits \\
\hline In January 2013 & Inventories (crude oil) & $191,169,240 \mathrm{VND}$ & \\
\hline \multirow{2}{*}{2 Sale of crude oil } & Cash & $114,701,544 \mathrm{VND}$ & \\
\hline & Revenue - sales of goods & & $114,701,544 \mathrm{VND}$ \\
\hline \multirow{2}{*}{3 Cost of sale } & Cost of goods sold & $95,584,620 \mathrm{VND}$ & \\
\hline & Inventories & & $95,584,620 \mathrm{VND}$ \\
\hline Total : & & $401,455,404$ VND & $401,455,404$ VND \\
\hline
\end{tabular}

Note:

The market price is $\$ 91.82 /$ bucket $x 100$ buckets $=\$ 9,182 \Leftrightarrow: \$ 9,182 \times 20,820(\mathrm{VND} / \mathrm{USD})=191,169,240 \mathrm{VND}$

Sale of crude oil and cost of sale: 114,701,544 VND = 50 buckets $x 2,294,031 \mathrm{VND} /$ bucket and then 95,584,620 VND=50 buckets $x 1,911,692$ VND/bucket.

\subsubsection{Second Economic Transactions}

The firm does not use swap contracts for purchase and sale of foreign currency with the Bank (Techcombank) as follows:

Table 8. - the exchange rate of payment

\begin{tabular}{|c|c|c|c|}
\hline Date and Explanation & Accounts & Debits & Credits \\
\hline $2 / 2013$ & Cash & $4,163,000,000 \mathrm{VND}$ & \\
\hline 1). Sale of foreign currencies & Amount of foreign currencies & & $4,144,000,000 \mathrm{VND}$ \\
\hline Difference of exchange rate & Sales revenue of foreign currencies & & $19,000,000 \mathrm{VND}$ \\
\hline \multicolumn{4}{|c|}{ 2). Purchase of foreign currencies } \\
\hline & Cash & & $2,515,200,000 \mathrm{VND}$ \\
\hline Total: & & $6,678,200,000 \mathrm{VND}$ & $6,678,200,000 \mathrm{VND}$ \\
\hline
\end{tabular}


Note:

Sale of foreign currencies: the exchange rate of payment: 4,163,000,000 VND =200,000 USD $x 20,815$ (VND/USD).

Historical exchange rate: 4,144,000,000 VND =200,000 USD $x 20,720(\mathrm{VND} / \mathrm{USD})$.

Difference of two exchange rates between the exchange rate of payment and historical rate: 19,000,000 VND equal to 200, 000 USD multiply [20,815 (VND/USD) minus 20,720(VND/USD)].

Purchase of foreign currencies, the spot rate: 2,515,200,000 VND =120, 000 USD $\times 20,960$ (VND/USD).

\subsubsection{Third Economic Transactions}

The firm does not also use option contracts to buy securities and the double entry is as follows:

Table 9. - the market price

\begin{tabular}{llll}
\hline $\begin{array}{l}\text { Date and } \\
\text { Explanation }\end{array}$ & Accounts & Debits & Credits \\
\hline $3 / 2013$ & Common Stocks & $110,000,000$ VND & \\
$\begin{array}{l}\text { Purchase } \\
\text { of securities }\end{array}$ & Cash & & $110,000,000$ VND \\
Total: & & $\mathbf{1 1 0 , 0 0 0 , 0 0 0}$ VND & $\mathbf{1 1 0 , 0 0 0 , 0 0 0}$ VND \\
\hline
\end{tabular}

Note:

Following the market price: $110,000,000 \mathrm{VND}=5,000$ shares $x 22,000$ VND/share.

\subsubsection{Final Economic Transactions}

The firm does not also use future contracts to buy Robusta coffee and the double entry is as follows:

Table 10.-the market price: 44,500,000 VND/ton

\begin{tabular}{|c|c|c|c|}
\hline $\begin{array}{l}\text { Date and } \\
\text { Explanation }\end{array}$ & Accounts & Debits & Credits \\
\hline $3 / 2013$ & $\begin{array}{l}\text { Inventories } \\
\text { (Robusta coffee) }\end{array}$ & $890,000,000 \mathrm{VND}$ & \\
\hline $\begin{array}{l}\text { Purchase of } \\
\text { Robusta } \\
\text { coffee }\end{array}$ & Cash & & $890,000,000 \mathrm{VND}$ \\
\hline Total: & & $890,000,000$ VND & $890,000,000$ VND \\
\hline
\end{tabular}

Note:

Following the market price: $890,000,000 \mathrm{VND}=20$ tons $x 44,500,000$ VND/ton.

Base of data analysis above, they are used to make financial reporting and the research results below:

\section{Research Results}

\subsection{The Result of Financial Statements, in Case the Firm Uses Derivative Instruments for Hedging Activ- ities}

From the table 1 to the table 5, the results of debit and credit balance of accounts are as follows the formula of debit balance and credit balance.

For assets

Debit balance equal to beginning debit balance plus increases in an account debit minus a decrease in account credit.

The debit balance of inventories (crude oil) equal to 0 VND plus 191, 169,240 VND minus 95, 584,620 VND equal to $95,584,620 \mathrm{VND}$.

The debit balance of inventories (foreign currencies) equal to $4,144,000,000$ VND plus 2, 515,200,000 VND minus 4, 144,000,000 VND equal to 2,515,200,000 VND.

The debit balance of inventories (Common Stocks) equal to 0 VND plus $115,000,000$ VND minus 0 VND equal to $115,000,000 \mathrm{VND}$.

The debit balance of inventories (Robusta coffee) equal to $0 \mathrm{VND}$ plus $890,000,000 \mathrm{VND}$ minus $0 \mathrm{VND}$ equal to $890,000,000$ VND.

The debit balance of cash equal to 0 VND plus $(114,701,544$ VND plus 4, 171,400,000 VND) minus $(2,502,720,000 \mathrm{VND}$ plus $90,000,000 \mathrm{VND}$ plus 5, 000,000 VND plus 814, 000,000 VND) equal to $874,381,544$ VND.

For equity and liabilities

Credit balance equal to beginning credit balance plus increase in the account credit minus decrease in account debit.

The credit balance of account payable equal to 0 VND plus 189, 087,240 VND minus 0 VND equal to 189 , 087,240 VND.

For Revenue, other comprehensive income and production and operating expenses

In case of other comprehensive income in table 1, we have to adjust between other comprehensive income and sales revenue of goods when the other comprehensive income is realized from the sale of crude oil and adjust it as follows:

Adjustment of price unit equal to 2,082,000 VND divide 100 buckets equal to $20,820 \mathrm{VND} /$ bucket, the adjusted amount of other comprehensive income equal to 50 buckets multiply 20,820 VND/bucket equal to 1,041,000 VND.

Adjustment of double entry:

Recognized increase in sales revenue of goods and rec- 
ognized decrease in other comprehensive income is 1,041,000 VND.

Other comprehensive income (debit): 1,041,000 VND.

Sales revenue of goods (credit): 1,041,000 VND.

\subsubsection{Why Adjustment?}

Assuming that 100 buckets of crude oil are sold, the result of table 1 is as follows:

In case of purchase: inventory of crude oil is $189,087,240$ VND (paid real price) plus 2,082,000 VND (unrealized gain).

In case of sale: real sale price is $229,403,100 \mathrm{VND}$, simultaneously, the sales revenue is also $229,403,100 \mathrm{VND}$ and inventory of crude oil $(189,087,240$ VND plus 2, $082,000 \mathrm{VND})$ is transferred to cost of sale.

The profit of the sale equal to Sales revenue minus Cost of sale minus other expenses (if any) equal to $229,403,100$ VND minus [89,087,240 VND plus 2, 082,000 VND (unrealized gain)] equal to $38,233,860 \mathrm{VND}$ leading to this is irrelevant. So, other comprehensive income is readjusted that recognized increase in sales revenue of goods and recognized decrease in other comprehensive income is 2,082,000 VND. Now, the other comprehensive income equal to 2,082,000 VND minus 2, 082,000 VND equal to $0 \mathrm{VND}$ and the profit of sale equal to $38,233,860 \mathrm{VND}$ plus 2, 082,000 VND equal to 40,315,860 VND. This case, all other comprehensive income is transferred to the profit of the sale. According to first economic transactions, the other comprehensive income is only realized as $1,041,000$ VND. So, it is transferred to the profit of sale as $1,041,000$ VND.

Other comprehensive income equal to 2,082,000 VND plus 12, 480,000 VND plus 20, 000,000 VND plus $76,000,000$ VND minus $1,041,000$ VND equal to 109 , 521,000 VND.

Revenue of Financial Activities $=27,400,000$ VND.

Sales revenue of goods $=114,701,544$ VND plus 1, 041,000 VND equal to $115,742,544 \mathrm{VND}$

Cost of goods sold $=95,584,620 \mathrm{VND}$

Table 11. The result of income statement and the result of balance sheet

\begin{tabular}{|c|c|c|}
\hline 1.The result o & f income statement & \\
\hline $\begin{array}{l}\text { Assumed current } \\
\text { exchange rate } \\
\text { is } 20,950 \mathrm{VND} / \mathrm{USD}\end{array}$ & VND Unit & Equivalent to $\$$ Unit \\
\hline 1). Revenue-sales & $115,742,544$ & $5,524.704$ \\
\hline 2). Cost of goods sold & $95,584,620$ & $4,562.512$ \\
\hline $\begin{array}{l}\text { 3). Profit - } \\
\text { sale = 1) - 2) }\end{array}$ & $20,157,924$ & 962.192 \\
\hline $\begin{array}{l}\text { 4). Revenue - } \\
\text { Financial Activities }\end{array}$ & $27,400,000$ & $1,307.876$ \\
\hline $\begin{array}{l}\text { 5). Financial } \\
\text { expense }\end{array}$ & 0,00 & 0,00 \\
\hline
\end{tabular}

\begin{tabular}{|c|c|c|}
\hline \multicolumn{3}{|c|}{ 6). Profit } \\
\hline \multicolumn{2}{|c|}{$\begin{array}{l}\text { Financial Activities }=4)^{27,400,000} \\
-5 \text { ) }\end{array}$} & $1,307.876$ \\
\hline $\begin{array}{l}\text { 7). Business profit } \\
\text { after Income } \\
\operatorname{Tax}=3)+6)\end{array}$ & $47,557,924$ & $2,270.068$ \\
\hline \multicolumn{3}{|l|}{ 8). Other } \\
\hline \multicolumn{3}{|l|}{ Income (gain/loss) } \\
\hline \multicolumn{3}{|l|}{$\begin{array}{l}\text { 9). Total } \\
\text { Profit = 7) - 8) }\end{array}$} \\
\hline \multicolumn{3}{|c|}{ 2. The result of balance sheet } \\
\hline \multicolumn{3}{|l|}{ A. Assets: } \\
\hline I. Currencies: 1) + 2) & $3,389,581,544$ & $161,793.868$ \\
\hline 1). Cash: & $874,381,544$ & $41,736.589$ \\
\hline 2). Foreign currencies & $2,515,200,000$ & $120,057.279$ \\
\hline $\begin{array}{l}\text { II. Short-term } \\
\text { III. investments }\end{array}$ & $115,000,000$ & $5,489.260$ \\
\hline 1). Common stocks: & $115,000,000$ & $5,489.260$ \\
\hline $\begin{array}{l}\text { IV. Inventories } \\
=1)+2)\end{array}$ & $985,584,620$ & $47,044.612$ \\
\hline 1). Crude oil: & $95,584,620$ & $4,562.512$ \\
\hline 2). Robusta coffee & $890,000,000$ & $42,482.100$ \\
\hline $\begin{array}{l}\text { Total Assets } \\
=\mathrm{I}+\mathrm{II}+\mathrm{III}\end{array}$ & $4,490,166,164$ & $214,327.741$ \\
\hline A. Liabilities: & $189,087,240$ & $9,025.644$ \\
\hline 1). Accounts payable & $189,087,240$ & $9,025.644$ \\
\hline $\begin{array}{l}\text { B. Equity = } \\
1)+2)+3)+4)\end{array}$ & $4,301,078,924$ & $205,302.097$ \\
\hline $\begin{array}{l}\text { 1). Investment } \\
\text { securities }(5,000 \text { shares })\end{array}$ & $115,000,000$ & $5,489.260$ \\
\hline $\begin{array}{l}\text { 2). Investment } \\
\text { capital }\end{array}$ & $4,029,000,000$ & $192,315.036$ \\
\hline $\begin{array}{l}\text { 3). Retained } \\
\text { Earnings }\end{array}$ & $47,557,924$ & $2,270.068$ \\
\hline $\begin{array}{l}\text { 4). Other } \\
\text { Comprehensive } \\
\text { Income (Gain/loss) }\end{array}$ & $109,521,000$ & $5,227.733$ \\
\hline Total & & \\
\hline $\begin{array}{l}\text { Liabilities \& } \\
\text { Equity: (A+ B) }\end{array}$ & $4,490,166,164$ & $214,327.741$ \\
\hline
\end{tabular}




\section{Firm Doesn'T Use Derivative Instruments for Hedg- ing Activities}

From the table 6 to the table 9 , the results of debit and credit balance of accounts are as follows:

The formula of debits balance and credit balance:

\subsubsection{For Assets}

Debit balance equal to beginning debit balance plus increase in an account debit minus decrease in account credit.

The debit balance of inventories (crude oil) equal to 0 VND plus 191,169,240 VND minus 95,584,620 VND equal to $95,584,620 \mathrm{VND}$.

The debit balance of inventories (foreign currencies) equal to $4,144,000,000$ VND plus $2,515,200,000$ VND minus 4,144,000,000 VND equal to 2,515,200,000 VND.

The debit balance of inventories (common stocks) equal to 0 VND plus $110,000,000$ VND minus 0 VND equal to 110,000,000 VND.

The debit balance of inventories (Robusta coffee) equal to 0 VND plus $890,000,000$ VND minus 0 VND equal to $890,000,000 \mathrm{VND}$.

The debit balance of cash equal to 0 VND $(114,701,544$ VND plus 4, 163,000,000 VND) minus (110,000,000 VND plus $890,000,000$ VND plus 2, 515,200,000 VND) equal to $762,501,544 \mathrm{VND}$.

\subsubsection{For Equity and Liabilities}

Credit balance equal to beginning credit balance plus increase in the account credit minus decrease in account debit.

The credit balance of account payable equal to $0 \mathrm{VND}$ plus 191,169,240 VND minus 0 VND =191,169,240 VND.

\subsubsection{For Revenue, Production and Operating Expenses} Revenue of financial Activities $=19,000,000$ VND.

Sales revenue of goods $=114,701,544$ VND.

Cost of goods sold $=95,584,620$ VND.

Table 12. The result of income statement and the result of balance sheet

The result of income statement

\begin{tabular}{|c|c|c|}
\hline $\begin{array}{l}\text { Assumed current } \\
\text { exchange rate } \\
\text { is } 20,950 \mathrm{VND} / \mathrm{USD}\end{array}$ & VND Unit & Equivalent to \$ Unit \\
\hline 1). Revenue-sales & $114,701,544$ & $5,475.014$ \\
\hline 2). Cost of goods sold & $95,584,620$ & $4,562.512$ \\
\hline 3). Profit - sale $=1)+2$ ) & $19,116,924$ & 912.502 \\
\hline $\begin{array}{l}\text { 4). Revenue - } \\
\text { Financial Activities }\end{array}$ & $19,000,000$ & 906.921 \\
\hline 5). Financial expense & 0,000 & 0,000 \\
\hline 6). Profit Financial & $19,000,000$ & 906.921 \\
\hline
\end{tabular}

\begin{tabular}{|c|c|c|}
\hline \multicolumn{3}{|l|}{ Activities =4) - 5) } \\
\hline 7). Business & & \\
\hline profit after & $38,116,924$ & $1,819.424$ \\
\hline \multicolumn{3}{|l|}{ Income Tax = 3) +6) } \\
\hline \multicolumn{3}{|l|}{ 8). Other } \\
\hline Comprehensive & 0,000 & 0,00 \\
\hline \multicolumn{3}{|l|}{ Income (gain/loss) } \\
\hline 9). Total Profit $=7)+8$ ) & $38,116,924$ & $1,819.424$ \\
\hline
\end{tabular}

\section{The result of balance sheet}

\begin{tabular}{|c|c|c|}
\hline $\begin{array}{l}\text { I. Currencies } \\
=1)+2)\end{array}$ & $3,277,701,544$ & $156,453.534$ \\
\hline 1). Cash & $762,501,544$ & $36,396.255$ \\
\hline 2). Foreign currencies & $2,515,200,000$ & $120,057.279$ \\
\hline $\begin{array}{l}\text { II. Short-term } \\
\text { investments }\end{array}$ & $110,000,000$ & $5,250.597$ \\
\hline 1). Common stocks & $110,000,000$ & $5,250.597$ \\
\hline III. Inventories $=1)+2$ ) & $985,584,620$ & $47,044.612$ \\
\hline 1). Crude oil & $95,584,620$ & $4,562.512$ \\
\hline 2). Robusta coffee & $890,000,000$ & $42,482.100$ \\
\hline $\begin{array}{l}\text { Total Assets } \\
=\mathrm{I}+\mathrm{II}+\mathrm{III}\end{array}$ & $4,373,286,164$ & $208,748.743$ \\
\hline A. Liabilities & $191,169,240$ & $9,125.023$ \\
\hline 1). Accounts payable & $191,169,240$ & $9,125.023$ \\
\hline $\begin{array}{l}\text { B. Equity } \\
=1)+2)+3)+4)\end{array}$ & $4,182,116,924$ & $199,623.720$ \\
\hline $\begin{array}{l}\text { 1). Investment } \\
\text { securities }(5,000 \text { shares })\end{array}$ & $110,000,000$ & $5,250.597$ \\
\hline 2). Investment capital & $4,034,000,000$ & $192,553.699$ \\
\hline 3). Retained Earnings & $38,116,924$ & $1,819.424$ \\
\hline 5). Other & & \\
\hline $\begin{array}{l}\text { Comprehensive } \\
\text { Income (Gain/loss) }\end{array}$ & 0,000 & 0,000 \\
\hline $\begin{array}{l}\text { Total Liabilities } \\
\text { \& Equity }(\mathrm{A}+\mathrm{B}) \text {. }\end{array}$ & $4,373,286,164$ & $208,748.743$ \\
\hline
\end{tabular}


Table 13. Comparative results of Balance sheet ((Unit: \$)

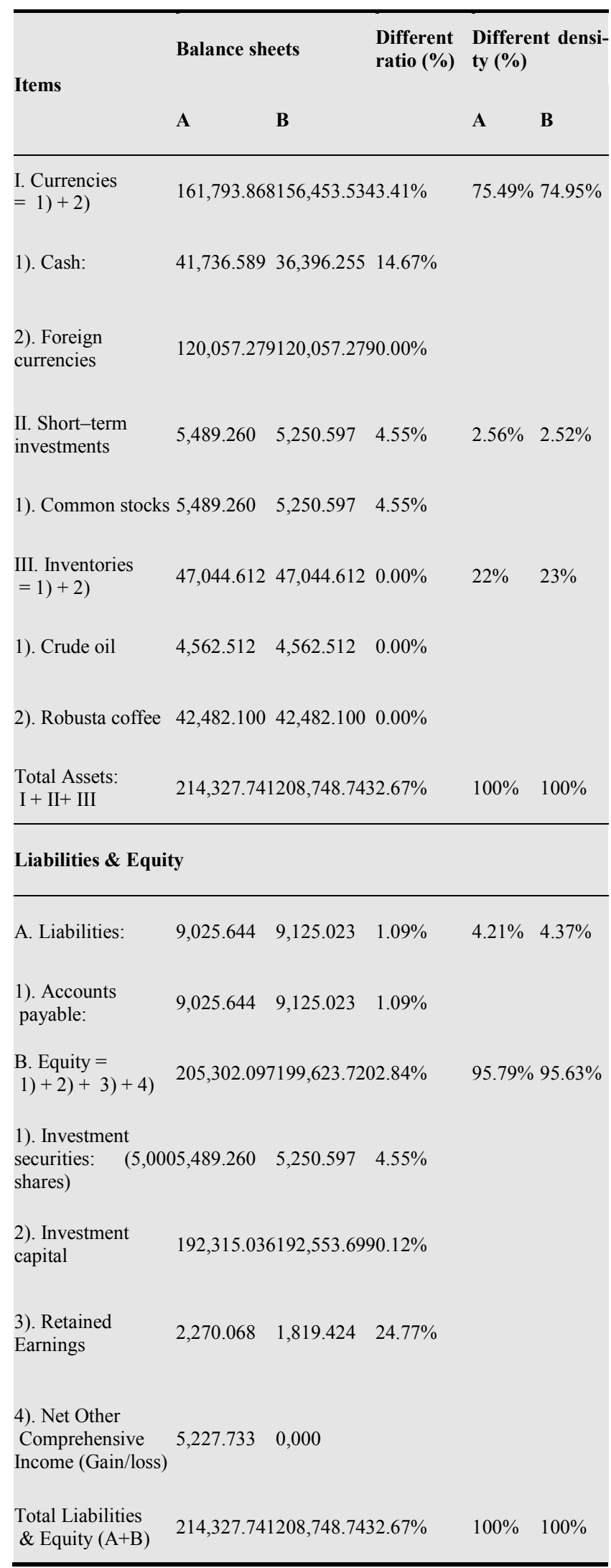

Table 14. Profitability ratio on financial statements $A \& B$

\begin{tabular}{|c|c|c|c|c|}
\hline \multirow{2}{*}{ No } & \multirow{2}{*}{ Profitability ratio } & \multicolumn{2}{|c|}{$\begin{array}{l}\text { Financial } \\
\text { statements }\end{array}$} & \multirow{2}{*}{$\begin{array}{l}\text { Different } \\
\text { ratio } \\
\text { A minus B }\end{array}$} \\
\hline & & $\mathbf{A}$ & B & \\
\hline 1 & $\begin{array}{l}\text { Return On Assets (ROA) } \\
=\text { after tax income /assets }\end{array}$ & $1.06 \%$ & $0.87 \%$ & $0.19 \%$ \\
\hline 2 & $\begin{array}{l}\text { Return On Equity (ROE) } \\
=\text { after tax income / equity }\end{array}$ & $1.11 \%$ & $0.91 \%$ & $0.19 \%$ \\
\hline 3 & $\begin{array}{l}\text { Liability ratio }= \\
\text { Liabilities / assets }\end{array}$ & $4.21 \%$ & $4.37 \%$ & $0.16 \%$ \\
\hline 4 & Debt ratio $=$ debt/equity & $4.4 \%$ & $4.6 \%$ & $0.17 \%$ \\
\hline 5 & $\begin{array}{l}\text { Current ratio = } \\
\text { current assets/ current liabilities }\end{array}$ & $2375 \%$ & $2288 \%$ & $87.00 \%$ \\
\hline 6 & $\begin{array}{l}\text { Market to book ratio = } \\
\text { security's price on } \\
\text { market/security's price of book- } \\
\text { ing }\end{array}$ & $109 \%$ & $114 \%$ & $4.94 \%$ \\
\hline 7 & $\begin{array}{l}\text { Quick ratio }= \\
\text { (cash securities } \\
\text { receivable)/current liabilities }\end{array}$ & $1793 \%$ & $1715 \%$ & $78.05 \%$ \\
\hline 8 & $\begin{array}{l}\text { Ratio of Return/revenue }= \\
\text { Net profit ( or profit after tax ) } \\
\text { revenue }\end{array}$ & $133.22 \%$ & $28.51 \%$ & $4.72 \%$ \\
\hline
\end{tabular}

\subsection{The Results of the Comparative Research Method and Impact Factors}

\subsubsection{The Impact Factors on Balance Sheet}

Supposing that in case the firm uses derivative instruments for hedging activities, the financial statement is (A) and in case the firm doesn't use derivative instruments for hedging activities, the financial statement is (B).

$$
\begin{gathered}
\text { Note: Ratio of } A_{i}=\frac{A_{i}-B_{i}}{B_{i}} \times 100 ;(i=1,2,3 \ldots . . n) ; \\
\text { Density of } A_{\mathrm{i}}=\frac{A_{\mathrm{i}}}{\sum_{i=1}^{n} A_{i}} \times 100 ; \\
\text { Density of } B_{\mathrm{i}}=\frac{B_{\mathrm{i}}}{\sum_{i=1}^{n} B_{i}} \times 100
\end{gathered}
$$

\subsubsection{The Impact Factors of Business Strategy}

Based on the results of the financial statements, the article analyses financial ratio to realize different results of two financial statements $\mathrm{A}$ and $\mathrm{B}$. These different results are foundations to assess the effects of use derivative instruments for hedging activities.

From the results above, the article discusses impact factors on hedge activities that the managers and investors are interested in. 


\section{Discussion of Impact Factors on Hedge Activities in Case of the other Invariable Factors}

The results above show that both of financial statements $\mathrm{A}$ and $\mathrm{B}$ are different in capital structure, assets and business results. Which factors do affect the different results of the two financial statements? Those are factors of the price volatility and the exchange rate volatility and other problems discussed below:

\subsection{The First Problem: Difference of Cash Ratio on the Balance Sheet}

According to the results above, there are differences in price and exchange rate (market price and forward price; inter-bank rate and forward rate).

\subsubsection{The Different Price}

The first economic transactions: the different price is equal to $\$ 90.82 /$ bucket minus $\$ 91.82 /$ bucket $=$ (1) USD/bucket $\mathrm{x} \quad 20,820 \quad(\mathrm{VND} / \mathrm{USD})=(20,820)$ $\mathrm{VND}$ /bucket (market price and forward price), equivalent ratio is (1.09)\%

The third economic transactions: the different price is equal to $18,000 \mathrm{VND} /$ share minus $22,000 \mathrm{VND} /$ share $=(4$, 000) $\mathrm{VND} /$ share (price of the call option and market price), equivalent ratio is $(18.18) \%$.

The final economic transactions: the different price is equal to $40,700,000 \mathrm{VND} /$ ton minus $44,500,000 \mathrm{VND} /$ ton $=(3,800,000) \mathrm{VND} /$ ton (future price and market price), the equivalent ratio is $(8.54) \%$.

The total impact ratio is equal to $(27.81) \%$. This case, the firm profits from the purchase when the forward price and future price are lower than the market price.

\subsubsection{The Different Exchange Rate}

Different exchange rate of sale and the different exchange rate are equal to 20,857 (VND/USD) minus 20,815 (VND/USD) equal to 42 VND (forward rate and inter-bank rate), equivalent ratio is $0.20 \%$. (The forward rate is higher than the interbank rate leading to increase in profit.

The different exchange rate of purchase and the different exchange rate are equal to 20,856 (VND/USD) minus 20,960 (VND/USD) equal to (104) VND (forward rate and inter-bank rate), equivalent ratio is $0.50 \%$ (contrary to sale, the forward rate is lower than the inter-bank rate leading to increase in profits).

\subsection{The Second Problem: Benefits of Derivatives for Hedging Activities}

Minimization of business risk: In the case of using derivative instruments to avoid risk of fluctuating prices and fluctuating exchange rates on the market. Because, the market price at the maturity date of the contract is higher than the expected price, the financial risks make the firm's capital to be reduced, but this decline will be compensated by the profits of the forward contracts. Actually, the firm has profit of $1.09 \%$ from forward contracts for the purchase of crude oil. In this case the firm has used forward contracts for hedging activities to avoid losses due to the volatility of market prices. The firm's assets are up $2.67 \%$. The formula (2) shows that if the firm purchases a big amount of commodities, the firm's profits will increase more from different price. In addition, the credit risks or unpayable risks on contract have an impact on the owner of the contract (receiver or payer), depending on the actual price volatility of the basis asset. Therefore, the use of derivative instruments for hedging activities helps the managers or investors avoid their financial risks, and they can immediately determine the future value of assets and master the market volatility. Assuming that the firm buys securities in condition of price volatility on the market from $15,000 \mathrm{VND} /$ share to $25,000 \mathrm{VND} /$ share. In this case, the company has determined the purchase price of the securities $(18,000 \mathrm{VND} /$ share $)$ at the maturity date of the contract and avoided the financial risks.

Benefits for the firm: Supposing that the firm applies derivative instruments for purchase and sale of commodity such as forward contracts, option contracts, future contracts and swap contracts. Each of the contracts brings different benefits to the firm. According to the assumption above, the firm has used forward price to purchase, it made the firm's profit increase by $\$ 2,082,000$, equivalently to the rate of $1.09 \%$. In case of foreign currency trading, the firm has also used the swap rate in foreign currency transactions with the bank, it brought profit of $0.7 \%$ (both buying and selling). In case, the firm has used future contracts to trade coffee as per the clearing method. Under this method, he can know the profit or loss daily. Table 5 shows that in February, the firm suffered losses due to low coffee prices, but in March, he profited by increased coffee prices. On settlement of the contract, the firm had a profit of $76,000,000 \mathrm{VND}$, equivalently to the rate of $8.54 \%$. Although the market price is lower than the future price or forward price or forward rate, the firm still avoids the financial risks. Because, the future price and forward rate are estimated on the basis of risk factors such as interest rate, return ratio and current price of the goods. For the option contracts, if it is disadvantageous for the firm, he will be unable to perform. So, the firm still controls their financial risks.

\subsection{The Third Problem: Different Ratio snd Different Density of both Balance Sheets}

\subsubsection{The Different Ratio}

The results of table 14 show different ratios between both financial reporting A and B as follows:

The currency ratio of financial reporting $\mathrm{A}$ is higher than the currency ratio of financial reporting B (4.41\%). This different ratio is affected by the price factors of goods and exchange rate factors. Use of derivative instruments makes purchase price decrease and sale price increase, leading to a higher currency ratio. However, the inventory ratio of 
financial reporting $\mathrm{A}$ is higher due to increased transaction fee of the call option. The inventories are evaluated following market prices, but the payment price follows the prices of derivative contracts. Normally, the inventory values of both financial statements are also evaluated by the market price.

The liability ratio of the financial reporting $\mathrm{A}$ is also lower than the liability ratio of the financial reporting $B$ $(1.09 \%)$ due to the effect of difference of the purchase price as analyzed above.

This special Other Comprehensive Income (Gain/loss) is only recognized for the financial reporting A when the firms apply derivative instruments for hedging activities and its value increases by $\$ 5,227.733$.

\subsubsection{Different Density}

The currency density of financial reporting $\mathrm{A}$ is higher than the currency density of financial reporting $\mathrm{B}$, equal to $75.49 \%$ minus $74.95 \%$ equal to $0.54 \%$, it means that the volatility of cash and short-term financial investments will be able to affect the ability of facing the debt maturity. Therefore, the increase in currency density of the financial reporting $\mathrm{A}$ is better than the currency density of the financial reporting $\mathrm{B}$. Besides, the inventory volatility also affects business processes from commodity reserve or production for sale. If the inventory density is too high, it will impact on inventory turnover. The relationship between currency density and inventory density on the financial reporting A shows that the currency density increases, but inventory density decreases. This is good for the firm's business. However, the relationship between currency density and inventory density on the financial reporting $\mathrm{B}$ is contrary with relationships between them on the financial reporting A.

For liability density, the results of table 13 show that the liability density of the financial reporting $\mathrm{A}$ is lower than the liability density on the financial reporting $\mathrm{B}$. If this density is too high leading to the firm will be bankrupt because of the firm's high debt and payment inability.

\subsection{The Fourth Problem: Profitability Ratio}

Profitability from the use of the assets: this ratio shows that the firm gets how much a profit unit about use of an asset unit.

ROA, the profitability ratio of asset unit on the financial report $\mathrm{A}$ is $1.06 \%$, it means that when the firm uses an asset unit, its profitability will be 0.0106 profit units. In case above, the firm uses asset of 4,490,166,164 VND to get profit of $47,557,924$ VND. If the return of the financial reporting $A$ is added up unrealized gain, the profitability of the asset will be higher than that as follows:

$$
\mathrm{ROA}=\frac{\$ 2,270.068+\$ 5,227.733}{\$ 214,327.741}=\frac{\$ 7,497.801}{\$ 214,327.741}=3.50 \%
$$

With $\mathrm{ROA}=3.50 \%$, the firm has $157,078,924$ VND from use of their assets.
ROA, profitability of assets in the financial statements $\mathrm{B}$ is $0.87 \%$, it means that the firm uses asset unit; its profitability is only $\$ 0.0087$ profit. If comparing ROA (A) with ROA (B), the different results are $3.50 \%$ minus $0.87 \%$ equal to $2.63 \%$. In case, he applies derivative instruments to hedge activities, his profit is higher. In fact, ROA of the financial statements $\mathrm{A}$ is $2.63 \%$ higher than ROA of the financial statements B.

Profitability of equity: This ratio shows how much the net profit is generated from the equity. Besides, the ROE is the most accurate measure to assess the accumulation of capital spending so that how much net profit is generated. This is also a reliable ratio of the profitability of the firm in the future. The ROE is often used by the investors to analyze stocks and compare to the same industry. It is also referenced when they decide to buy shares of any company. Specially, the firm's ROE ratio is as high as possible. It means that the effective use of their capital is good. So the ROE is higher and the stock is more attractive to the investors. From this reason, profitability of equity generated from the use of equity in the financial statements $\mathrm{A}$ is $1.11 \%$, it means that when the firm uses an equity unit, he gets 0.011 profit units. If the return is added up unrealized gain, the ROE is higher as follows:

$$
\mathrm{ROE}=\frac{4 \$ 2,270.068+\$ 5,227.733}{\$ 205,302.097}=\frac{\$ 7,497.801}{\$ 205,302.097}=3.65 \%
$$

This case, the firm's equity has generated more profits. When the firm uses equity, he will get 0.037 VND profit units. The profitability of equity on the financial reporting $\mathrm{B}$ is only $0.91 \%$. Comparing the results of the ROE (A) and $\operatorname{ROE}(\mathrm{B})$ is $3.65 \%$ minus $0.091 \%$ equal to $3.56 \%$, the profitability of equity of the financial statements A is higher than the profitability of equity on the financial statements B $(3.56 \%)$.

\subsubsection{Liability Ratio}

This ratio measures how much percentage of the firm's the assets from borrowing and shows the financial autonomy ability of the firm. If the ratio is too small, the firm's asset is borrowed less. If the ratio is too high, Almost the firm's assets are borrowed, leading to affect his competitiveness. This also implies the level of the higher business risks. The hypothesis above shows that the liability ratio of the financial reporting $\mathrm{A}$ is lower than liability ratio of financial reporting $\mathrm{B}(0.16 \%)$ due to using hedge instruments.

\subsubsection{Debt Ratio}

This ratio is a relationship between borrowing and equity. If this ratio is small, it means that the firm is less dependent on his borrowing and the financial risk is low. In principle, this ratio is small, which means that the liability is a small proportion of the total assets or equity, leading to the firm gets less financial difficulties. If the ratio is greater, the firm will get difficulties in debt paying ability or bankrupt. According to this principle, the debt ratio of the fi- 
nancial report $\mathrm{A}$ is compared with the debt ratio of the financial statements $\mathrm{B}$, it is lower $(0.17 \%)$, it means that the financial risks on the financial statements $\mathrm{A}$ reduce by $0.17 \%$.

\subsubsection{Current Ratio}

Solvency of the firm is a financial capacity that he can get to meet payment demands of his debt to other individuals or organizations related to the firm's loan or debt. Therefore, if the current ratio is higher, the firm's solvency will be higher. If this ratio is less than one, his business assets are not enough to immediately pay the current liabilities of coming due. So the article views the difference ratio between the current ratio of the financial reporting $A$ and the current ratio of the financial reporting $\mathrm{B}$, the result shows that the current ratio of the financial reporting $A$ is higher than the current ratio of financial reporting $\mathrm{B}(87 \%)$. This demonstrates that when the firm applies derivative instruments for hedging activities, this result affects the firm's solvency.

\subsubsection{Market to Book Ratio (P/B)}

The ratio means relating to the safety of long-term investments. $\mathrm{P} / \mathrm{B}$ also shows that the investors are willing to pay stock price that are much higher than the book value. This ratio is only really useful when the investors consider which firms have high capital level or financial firms. Because the asset value of these firms is relatively large. However, the accuracy of the $\mathrm{P} / \mathrm{B}$ depends on the application of accounting standards and inconsistent value is sometimes distorted by accounting tricks. The book value sometimes does not reflect the real value of shares leading to $(\mathrm{P} / \mathrm{B})$ will become inaccurate. Therefore, when using two different methods, leading to the difference ratio. This result will directly affect investment when he analyzes data on the financial statements. From the results in Table 14, comparing the ratio of the financial statements A with the ratio of the financial statements $\mathrm{B}$, it reduces by $4.94 \%$. Why it reduces? Because the firm purchases a call option to ensure his financial security. If the stock price disadvantage to the firm's profit, maybe he doesn't realize this transaction. So he is not damaged to his finances, but he has to pay a transaction fee for the call option. As a result, the ratio reduces by $4.94 \%$, this percentage also increases his financial safety.

\subsubsection{Quick Ratio}

Quick ratio shows comparable relationship between cash and cash equivalents with short-term debt. The cash equivalents are considered as assets with fast money circulation speed (short-term investments, short-term receivables). This quick ratio is shown on the firm's health status of short-term finance. Under this principle, if the coefficient of liability solvency is higher, the firm's health status of short-term finance is good and vice versa. This coefficient is equal to one or greater, indicating the ability to meet higher debt payment for the short-term debts. Therefore, the firm does not get into financial trouble when he needs immediate payment for the short-term debts. Conversely, if the ratio is less than one, the firm will not be able to immediately pay all short-term debts or the firm will meet financial difficulty when he cannot immediately pay the shortterm debts. In this case, the quick ratio of the financial reporting $\mathrm{A}$ is higher than the quick ratio of the financial reporting B (78.05\%). Because, the firm applies derivative instruments for hedging activities to prevent financial risk from the firm's insolvency and it increases by $78.05 \%$.

\section{Conclusion}

The effect of accounting method: Use of the accounting methods plays an important role in the recognizing process of accounting data and making financial statements. Therefore, the accounting policy must conform to the firm's application. The resulting analysis above demonstrates that the use of two accounting methods will lead to the two different results. Thus, countries need to develop accounting principles and methods, which should be based on fluctuation factors of price and exchange rate on the market to ensure the value of assets or liabilities in business process. Outcome analysis also indicates that hedge accounting brings great profit to the firms and investors. Simultaneously, it also minimizes the risks.

The impact factors of market price and exchange rate: Business process, asset value and liability are volatile due to the impact of market prices. So, the firms should use derivative instruments to minimize the risks. The data analysis above also shows that the use of derivative instruments for hedging activities brings high effectiveness to the firms. Comparing the financial statements A with the financial statements B, all of the above criteria in financial statements A give the relevance and reliability of accounting data to the managers or investors. The accounting policy makers, managers and investors need to consider the following issues:

For the whole draft of the accounting policy: they should consider impact factors such as volatility of market prices, volatility of exchange rates and volatility of interest rates etc., especially, the factors affecting to financial markets. Because, the financial market directly affects economic development. In 2008, the evidence of economic crisis shows that the economic crisis was affected by financial market downturn (bad debt, freeze investment property etc.). Therefore, the drawing up accounting principles need to view the factors of financial risks, simultaneously combine with the principles of financial analysis to find out the basic factors affecting the financial markets. The article combines the two methods that are the method of accounting and financial analysis to find out the basis factors affecting the profitability ratio. Particularly, developing countries and countries with transition economy should consider the tendency of economic development of their own country and combine with the international accounting standards to draw up their own accounting principles, which are relevant to their own economic development 
process.

The managers need to consider financial hedging activities. Because, the financial risks are potential risks that the managers cannot anticipate. Hedge accounting is essential to their safety of principal on the business. The financial reporting A shows the higher assets, higher profits and equity increase. Besides, the managers also avoid the volatility of market prices and exchange rates. Above analysis results are also proof of hedge accounting effectiveness. In addition, the results are also references for the firms to apply evaluation methods of the fair value of the financial asset or financial liability and help the firms use accounting methods for economic events that occur.

The investors are interested in the relevance and reliability of information on the financial reporting. Thus, the analysis of the profitability ratio above helps the investors invest in the firms with the highest profitability and the data in the financial statements are the foundation for the analysis of the investors. The results of the two financial statements A and B show the difference of the profitability ratio of the firms that the investors want to invest. Therefore, the investors analyze the accounting data of any the firms' financial statements. They also have to consider the accounting methods and the use of derivative instruments for hedging activities.

\section{References}

[1] Benzion Barlev And Joshuarene Haddad, Fair Value Accounting And The Management of The Firm, Critical Perspectives on Accounting 2003, 14, 383-415.

[2] Christian Laux and Christian Leuz, 2009, Did Fair Value Accounting Contribute To The Financial Crisis?, NBER Working Paper, No. 15515.

[3] Creative Solutions at Deloitte, Johannesburg, Hedge Accounting Adapting to change.

[4] Christian Laux, Christian Leuz, 2009, The crisis of fair value accounting: Making sense of the recent debate, Accounting, Organizations and Society 34 826-834.

[5] Cristina Aurora BuneaBontag, Basic Principles of Hedge Accounting, MPRA Paper No. 17072, posted 3. September 2009.

[6] Denis and william mann, Ridget gandy,Roger merritt, Mark oline, Joseph ST, Hedge Accounting And Derivatives Studyfor Corporates Disclosure, Hedge Accounting, And Restatement Risk, (2005), Journal of Derivatives Accounting, Vol. 2, No. 2 .

[7] Ernst \& Young, Hedge accounting under IFRS 9 - a closer look at the changes and challenges.

[8] Financial Accounting Standards Board, 1991, Statement of Financial Accounting Standards No.107.

[9] Financial Accounting Standards Board, 2006, Statement of Financial Accounting Standards No.155.

[10] Financial Accounting Standards Board, 2000, FAS138: Accounting for Certain Derivative Instruments and Certain
Hedging Activities.

[11] Financial Accounting Standards Board, 1990, FAS105: Disclosure of Information about Financial Instruments with OffBalanceSheet Risk and Financial Instruments with Concentrations of Credit Risks.

[12] Financial Accounting Standards Board, 1993, FAS115: Accounting for Certain Investments in Debt and Equity Securities.

[13] Financial Accounting Standards Board, 1998, FAS133: Accounting for Derivative Instruments and Hedging Activities.

[14] Financial Accounting Standards Board, 1998, FAS149: Amendment of Statement 133 on Derivative Instruments and Hedging Activities.

[15] Guy Coughlan, Simon Emery And Johannes Kolb, 2004, HeatTM (Hedge Effectiveness Analysis Toolkit): A Consistent Framework For Assessing Hedge Effectiveness Under Ias 39 And Fas 133, From Jpmorgan, Journal of Derivatives Accounting, Vol. 1, No. 2, 221-272.

[16] G. Ryan Professor and Peat Marwick Faculty, (2008), Fair Value Accounting: Understanding The Issues Raised, New York University.

[17] Henk Berkman, Michael E. Bradbury, Phil Hancock and Clare Innes, 2002,Derivative financial instrument use in Australia, Accounting and Finance (42) 97- 109.

[18] Haiwen Zhang, 2009, Effect of derivative accounting rules on corporate riskmanagement behavior, Journal of Accounting and Economics 47 244-264.

[19] Historical Cost and Fair Value Accounting: Relevance and Reliability

Revisited: http://businessaccountingguides.com/historicalcost/.

[20] International Accounting Standard Board "IASB", 2009, IFRS 9 : Financial Instruments.

[21] International Accounting Standard, 2008, IAS 39 (Financial Instruments: Recognition and Measurement).

[22] International Accounting Standar, 2008,IAS 32 (Financial Instruments: Presentation).

[23] International Accounting Standard , 2008, IFRS 7 ( Financial Instruments: Disclosures).

[24] International Accounting Standard, 2008, IAS 40 (Investment Property).

[25] International Accounting Standard, 1991, IAS 30 (Disclosures in the Financial Statements of Banks and Similar Financial Institutions).

[26] International Accounting Standard, 2008, IAS 38 (Disclosures Intangible Assets).

[27] International Accounting Standard, 2008, IAS 16 (Property, Plant and Equipment).

[28] International Accounting Standard, 2008, IAS 2 (Inventories).

[29] International Accounting Standard Board "IASB" , 2008, IAS 39: Financial Instruments: Recognition And Measurement. 
[30] International Accounting Standard Board "IASB", 2008 , IAS 21: The Effects of Changes in Foreign Exchange Rates.

[31] Jannis Bischof and Michael Elbert, 2007, "IAS 39 and basis in rick perception of financial instruments", Universitat Mannheim, Deutsche.

[32] James n. Bodurtha, JR, 2005, divergent fas133 and ias39 interest rate risk Hedge effectiveness: problem and remedies, Journal of Derivatives Accounting, Vol. 2, No. 1.

[33] Journal of Accounting Auditing and Finance, Implications of firm heterogeneity for the accounting of cash flow hedges under SFAS 133

[34] Joanne Horton And Richard Macve, 2000, "Fair value" For Financial Instruments: How Erasing Theory is leading To Unworkable Global AccountingStandard Performance Reporting is written, Australian accounting reviews, vol. 11 No2 .

[35] June F. Li, Ph.D., CPA (Inactive), Fair Value Option, Tennessee CPA journal, 2006.

[36] Kristin Orrell and Laura D'Albey, 2012, Accounting for Derivatives and Hedging:Introduction to Issues Commonly Observed in Practice, PricewaterhouseCoopers LLP.

[37] Kevin Ow Yong, Fair Value Accounting: SFAS 157 and IAS 39 2of 6: www.qfinance.com.

[38] Lil E. Crawford, ArletteC. Wilson and BarryJ. Bryan, Using and Accountingfor Derivatives: An InternationalConcern, Journal of InternationalAccounting,Auditing \& Taxation, 6(1): 111121.

[39] Mike Loritz and Tim Woods, 2012, MHM Executive Education Series: MHM Executive EducationSeries:Derivatives and Hedging

[40] Ministry of Finance, 2009, Circular No. 210/2009/CMOF,. Bộ tài chính, Thông tư số $210 / 2009$, ban hành ngày 06/11/2007.

[41] Minister of Finance, (2001), Vietnam accounting standard 2 (Inventories). Chuẩn mực kế toán Việt nam số 2 ( hàng tồn kho), ban hành ngày $31 / 12 / 2001$.

[42] Minister of Finance, 2001,Vietnam accounting standard 3 (Tangible fixed assets. Bộ Tài Chính, Chuẩn mực kế toán Việt nam số 3 ( Tài sản cố định hữu hình), ban hành ngày $31 / 12 / 2001$

[43] Minister of Finance, 2005, Vietnam accounting standard 22 ((Disclosures in the Financial Statements of Banks and Similar Financial Institutions). Bộ Tài Chính, Chuẩn mực kế toán Việt nam số 3 (Trình bày bổ sung báo cáo tài chính của các ngân hàng và tổ chức tài chính tương tự), ban hành ngày $15 / 02 / 2005$.

[44] Minister of Finance, 2003, Vietnam accounting standard 5 (Investment property). Bộ Tài Chính, Chuẩn mực kế toán Việt nam số 5 ( Tài sản cố định hữu hình), ban hành ngày $30 / 12 / 2003$

[45] Minister of Finance, 2001, Vietnam accounting standard 4(Intangible fixed assets). Bộ Tài Chính, Chuân mực kế toán Việt nam số 4 ( Tài sản cố định vô hình), ban hành ngày $30 / 12 / 2003$.

[46] Ministry of Finance, 2006, Decision No. 15/2006/QDMOF. Bộ tài chính, Quyết định số 15/2006/BTC ban hành $15 / 7 / 2006$

[47] Ministry of Finance, 1995, Decision No. 1141 TC/QĐ/CĐKT. Bộ Trưởng Tài Chính, Quyết định số. 1141 - TC/QĐ/CĐKT, ban hành ngày $1 / 11 / 1995$.

[48] Ministry of Finance, 2001, Decision No. 149/2001/QĐBTC Bộ Trưởng Tài Chính, Quyết định số 149/2001/QĐBTC, ban hành ngày $31 / 12 / 2001$.

[49] Ministry of Finance, 2002, Decision No. 165/2002/QĐBTC. Bộ Trưởng Tài Chính, Quyết định số 165/2002/QĐBTC, ban hành ngày $31 / 12 / 2002$.

[50] Ministry of Finance, 2003, Decision No. 234/2003/QĐBTC. Bộ Trưởng Tài Chính, Quyết định số 234/2003/QĐBTC, ban hành ngày $31 / 12 / 2003$.

[51] Ministry of Finance, 2005, Decision No. 12/2005/QĐBTC. Bộ Trưởng Tài Chính, Quyết định số 12/2005/QĐBTC, ban hành ngày 15 tháng 02 năm 2005.

[52] Ministry of Finance, 2005, Decision No. 100/2005/QĐBTC. Bộ Trưởng Tài Chính, Quyết định số 100/2005/QĐBTC, ban hành ngày 28 tháng 12 năm 2005 .

[53] PricewaterhouseCoopers, Similarities and Differences A Comparison of IFRS and Thai GAAP, Vietnamese GAAP, Cambodian GAAP and Laos GAA.

[54] PricewaterhouseCoopers LLP, Fair value accounting: Tax considerations.

[55] Robert H. Herz, Frederick J, and Brian J. Bushee, Derivatives: were 1994 Disclosures Adequate?, the journal of Corporate Accounting and Financial/Winter 19951996

[56] Stephen Spector, Ma, Fcga, 2009, International Accounting Standard 39 (IAS 39), Financial Instruments: Recognition and Measurement, CGACanada.

[57] Web site: www.acsbcanada.org.

[58] http://www.thesaigontimes.vn/Home/taichinh/chungkhoan/ 83489/Baocaotaichinhnenhuongtoinhadautu.html.

[59] http://www.investopedia.com/terms/h/historicalcost.asp\#ixz z2FGfBbQQo;

[60] http://businessaccountingguides.com/historicalcost/.

[61] http://en.stockbiz.vn/News/2012/1/3/262166/vietnamstock marketlosesover10bofcapitalizationin2011.aspx.

[62] http://giacaphe.com/giacaphetructuyen/.

[63] http://www.cophieu68.com/atbottom.php.

[64] http://www.sggp.org.vn/tigiangoaite/2012/12/308119/.

[65] http://www.tapchitaichinh.vn/NhandinhDubao/Thitruongda uthothegioinam2012vatrienvong2013/19863.tctc. 